\title{
New approaches to communicating and educating through the use of historical maps
}

\author{
Milena Bertacchini ${ }^{\text {a, }}$, Laura M. Turchi ${ }^{\mathrm{b}}$ \\ ${ }^{a}$ University of Modena and Reggio Emilia, Department of Chemical and Geological Sciences, Gemma Museum, \\ milena.bertacchini@unimore.it \\ ${ }^{b}$ University of Modena and Reggio Emilia, Department of Studies on Language Culture, laura.turchi@unimore.it \\ * Corresponding author
}

\begin{abstract}
The Coronavirus pandemic has highlighted the difficulties that sometimes accompany the consultation of historical cartographic repertoires. At the same time, it has brought to the forefront the relationship between digital content and cultural fruition. The project here presented has launched the digitalization of historical maps dated between the $16^{\text {th }}$ and $17^{\text {th }}$ centuries and selected by the collection of the Este Maps of the Military Series preserved at the State Archive of Modena and the Modena and Reggio Emilia University's Gemma Museum. Every digitized map is supported by a descriptive caption detailing its cartographic characteristics and historical context. The project intends to promote research, study and fruition, using new technologies for more effective and dynamic science communication and education, both triggering activities with high schools related to thematic studies or work experience, and creating a virtual exhibition to overcome any structural, cultural and health barriers in order to involve users in an experience of discovery, knowledge and individual learning.
\end{abstract}

Keywords: digitalisation, cultural heritage, education

\section{A heritage to be enhanced and made usable}

Historical Cartography is a fascinating science that, using maps, restores authentic fragments of the past of a land in a given historical and cultural moment. Historical maps are often real works of art for their refinement, elegance and chromatisms. They are living records of epochs, techniques, cultures, men and territories (Rombai, 2010), which makes them important to enhance and make known, especially to the citizens of the future.

The powerful expressive force that characterizes historical maps is communicated using a language of codes (Dai Prà, 2010), which often makes their narrative interpretation difficult without appropriate symbolic mediation, which provides a temporal insight into that given moment and of the living of that land by the men of that time (Farinelli, 1992).

According to Baker (2005) "la géographie ne peut se comprendre sans l'histoire".

This is the case, for example, of the collection of the Mappe Estensi of the Military Series preserved at the State Archive of Modena, ASMO (Cremonini, 2017) and dated between the $16^{\text {th }}$ and $17^{\text {th }}$ centuries, together with more recent maps of the House of Este preserved at Modena and Reggio Emilia University's Gemma Museum (Gemma).

The Este cartographic repertoire, which ASMO and Gemma collect, is a heritage little known to the public, telling of the House of Este and its control, originally over the Duchy of Ferrara (1471-1598), then over the Duchy of Modena and Reggio Emilia (1598-1859), when Modena was the capital (Federzoni, 2001). This patrimony accurately describes the territories of the Duchy with their changes and the neighbouring lands and States with which the Este had international relations, which are nowadays part of the European Union. The "undertakings" that these extraordinary documents testify constitute the oldest visual memory of the Este power. These records are inserted into landscapes, sometimes having disappeared or been forgotten, in which present-day cities, such as Modena, and the Emilia Romagna Region, and Europe are rooted.

The examples of the Este cartographic heritage taken into account are unfortunately devoid of any documentary sources that may be useful to reconstruct their historical context and the reasons that justified their drafting.

\section{The value of digitalisation}

The Coronavirus pandemic and the continuation of the national health emergency have highlighted the difficulties that sometimes accompany the consultation of historical cartographic repertoires. At the same time, they have brought to the forefront the role that digital technology can play in facilitating the fruition and understanding of this heritage.Enhancing and making these cartographic collections usable means promoting awareness, interpretation and participation, overcoming any kind of barrier to their fruition.

The recently launched digitalisation of these historical maps allows access to a multitude of data. On one hand, it offers scholars an extraordinary opportunity for research, and on the other, it becomes a powerful medium to convey and provide a wider audience with the accessibility of a 
heritage that is as precious as it is often undetected or little known.

This important data collection, which can be implemented and consulted in different ways, represents a piece of a larger context that leads to a synthesis of historical, cultural or political events, and an archive of the Este and Modenese history.

The relationship between digital content and cultural fruition (the rapidly developing field of study known as Digital Humanities) reinforces the sense of belonging and rediscovery of historical memory that links local and regional heritage to the roots of Europe.

Digitising the cartographic collection enhances and makes usable what may not otherwise be accessible due to preservation issues or preciousness, without compromising the task of safeguarding it. Moreover, it is a tool for enriching learning and knowledge: dynamic, enjoyable by anyone, available over time, usable in an innovative and experiential way, and also implementable based on personal interests and needs.

\section{Aims of the project}

The project presented here, entitled "Experiences of promotion and fruition using historical maps", aims to improve awareness and knowledge of the Este cartographic heritage preserved at ASMO and Gemma in order to promote research, study and fruition, using new technologies for more effective and dynamic science communication and education.

The project structure is divided into four different major phases. 1. Recognition, referring to the systematic recognition of the repertoire of maps (consisting of over 200 documents); 2. Selection, aimed at selecting the ones that are most suitable for the process of high-definition digitalisation (a maximum of 35); 3. Digitalisation, i.e. the digital restitution of each representation; 4. Classification schedule, referring to the descriptive caption detailing the cartographic characteristics.of each digitised map. Each caption will also show elements that are useful in reconstructing the historical context of the maps and stimulating a narrative dialogue incorporating history, cartography and land, so as to promote better public understanding. Each brief text will describe the history of the Este Duchy of Modena and Reggio Emilia and its neighboring and foreign territories with which the Este had political, economic and cultural relationships.

The cartographic maps taken into consideration illustrate historical events that took place between the 16th and 17th centuries. They offer an interesting insight into the Este dynasty and the changing diplomatic relations during the Duchy of Modena and Reggio by Cesare I (1598-1628),

1 The Thirty Years' War is sometimes also called The European Civil War (1618-1648). It was a series of violent clashes fought over most of Europe. This war began as a religious war, fought between Roman Catholics and Protestants in Germany. It developed into a political struggle between the Catholic Habsburgs of the Holy
Alfonso III (1628-1629), Francesco I (1620-1658) e Alfonso IV (1658-1662). These maps have often been the expression of the refined skills of technical experts, such as plumbers, surveyors and architects, who used cartographic drawing as a valuable tool to give concreteness to projects of various kinds (Rossi, 2006) and add luster to the dynasty. They are presented as careful and precise depictions of important battles and fortified towns under siege, allowing us to grasp the military techniques of the time, sometimes together with particular narratives that tell of life in the besieged territories.

\section{A glance at the selected maps}

The selected maps tell us of besieged and fortified cities and battle sites, from Lützen (Germany) to Candia (Greece), from Alessandria to Casal (Casale Monferrato) to Mantua and Modena (Italy). The study of these maps has highlighted new and interesting elements about the cartographic production of Este Duchy during the $16^{\text {th }}$ and $17^{\text {th }}$ centuries.

Each map selected is related to a specific schedule composed of some descriptive sections on the main cartographic characteristics of the map, which are also useful for its cataloguing; the reconstruction of the historical context in which the event on the map takes place; observations and comments on the value and meaning that the representation wanted to convey and still communicates. The current experimentation was based on the thesis work of a student on the Master's degree course of Education and Communication of Sciences of the Modena and Reggio Emilia University (Di Ponzio, 2021), whose assistant supervisors were the Authors of this paper. By way of example, here are the descriptive sheets of the maps relating to the siege of the cities of Lützen (SaxonyAnhalt, Germany) and Alessandria (Piedmont, Italy).

\subsection{A Map of the battle of Lützen}

\subsubsection{Historical context}

During the $16^{\text {th }}$ and $17^{\text {th }}$ centuries most of the northern Italian states were natural allies of Spain and the Empire, as was the Este Duchy. Francesco I's alliance with the Spanish during the Thirty Years' War ${ }^{1}$ allowed the Este family to take possession of some territories including the city of Correggio (Gasser, 2001). The Este were involved in real "European wars", involving most of the states of today's Europe in games of shifting alliances according to political, military, but also economic logic.

The territory of Lützen, which was located in the German region of Saxony belonging to the Holy Roman German Empire, was the scene of a decisive event in the Thirty Years' War, which began for religious reasons.

Roman Empire (Austria, most of the German princes and occasionally Spain). They were opposed by Denmark, Sweden, Catholic France and the Protestant princes of Germany. 


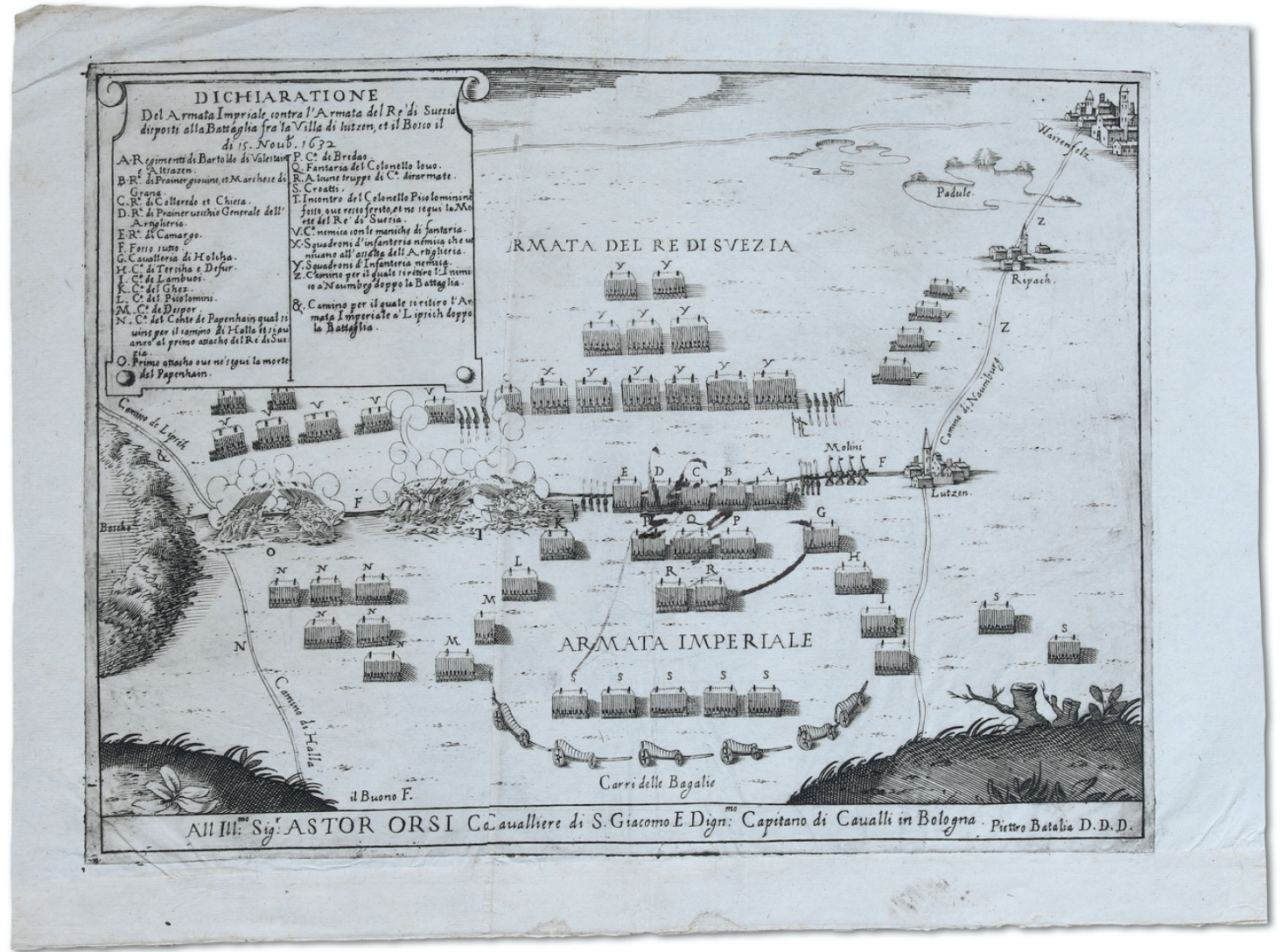

Figure 1. A Map of the Battle of Lützen (etching and engraving, printed on paper, ASMO Mappario Estense, Serie Generale, 95).

\begin{tabular}{|c|c|}
\hline People involved & Anonymous \\
\hline Physical properties & Watermark: Indistinct. Condition: fold line on upper left corner. Verso: none \\
\hline Measurements & 28.7 x $38.6 \mathrm{~cm}$ (image and sheet) \\
\hline \multirow[t]{4}{*}{ Transcriptions } & $\begin{array}{l}\text { Printed title: Dichiaratione del Armata Imperiale contra l'Armata del Re di } \\
\text { Svezia disposti alla Battaglia fra la Villa di Lutzen, et il Bosco il dì } 15 \text { novb. } \\
1632 \text { [top left, in rectangular panel,] }\end{array}$ \\
\hline & $\begin{array}{l}\text { Dedication: All' Ill. }{ }^{\text {mo }} \text { Sig. }{ }^{\mathrm{r}} \text { ASTOR ORSI Cavalliere di S. Giacomo E Dign. }{ }^{\mathrm{mo}} \\
\text { Capitano di Cavalli in Bologna. Pietro Batalia D.D.D. [bottom, in rectangular } \\
\text { panel across top of map] }\end{array}$ \\
\hline & Additional text: a key, A-O, P-\& [top right, in rectangular panel, below title] \\
\hline & Annotations: (Recto) Lutzen 149, black pencil (Verso) none \\
\hline Places & $\begin{array}{l}\text { Lützen, Saxony-Anhalt, Germany }\left(51^{\circ} 15^{\prime} 24^{\prime \prime} \mathrm{N} 12^{\circ} 08^{\prime} 29^{\prime \prime} \mathrm{E}\right) \\
\text { Ripach (Rippach), Saxony-Anhalt, Germany }\left(51^{\circ} 13^{\prime} 59^{\prime \prime} \mathrm{N} 12^{\circ} 04^{\prime} 00^{\prime \prime} \mathrm{E}\right) \\
\text { Waisenfelz (Weißenfels), Saxony-Anhalt, Germany }\left(51^{\circ} 12^{\prime} \mathrm{N} 11^{\circ} 58^{\prime} \mathrm{E}\right)\end{array}$ \\
\hline Date & $15^{\text {th }}$ November 1632 \\
\hline
\end{tabular}

Table 1. The main cartographic features of the Map of the battle of Lützen (fig. 1).

At Lützen, the army of the Protestant King Gustav II Adolf of Sweden decided to attack the Habsburg (and Catholic) imperial army led by Albrecht von Wallestein. In the battle, which was fought between 6th and 16th November 1632, the Swedish armies won despite the death of King Gustav of Sweden.
During the first years of his rule, Francesco I d'Este was careful to respect the bonds of obedience that bound him as a vassal to the Emperor, such as that of providing as much aid as possible to the imperial army. He sent two of his uncles, princes Borso and Foresto, who distinguished themselves for their valour, to Lützen. 

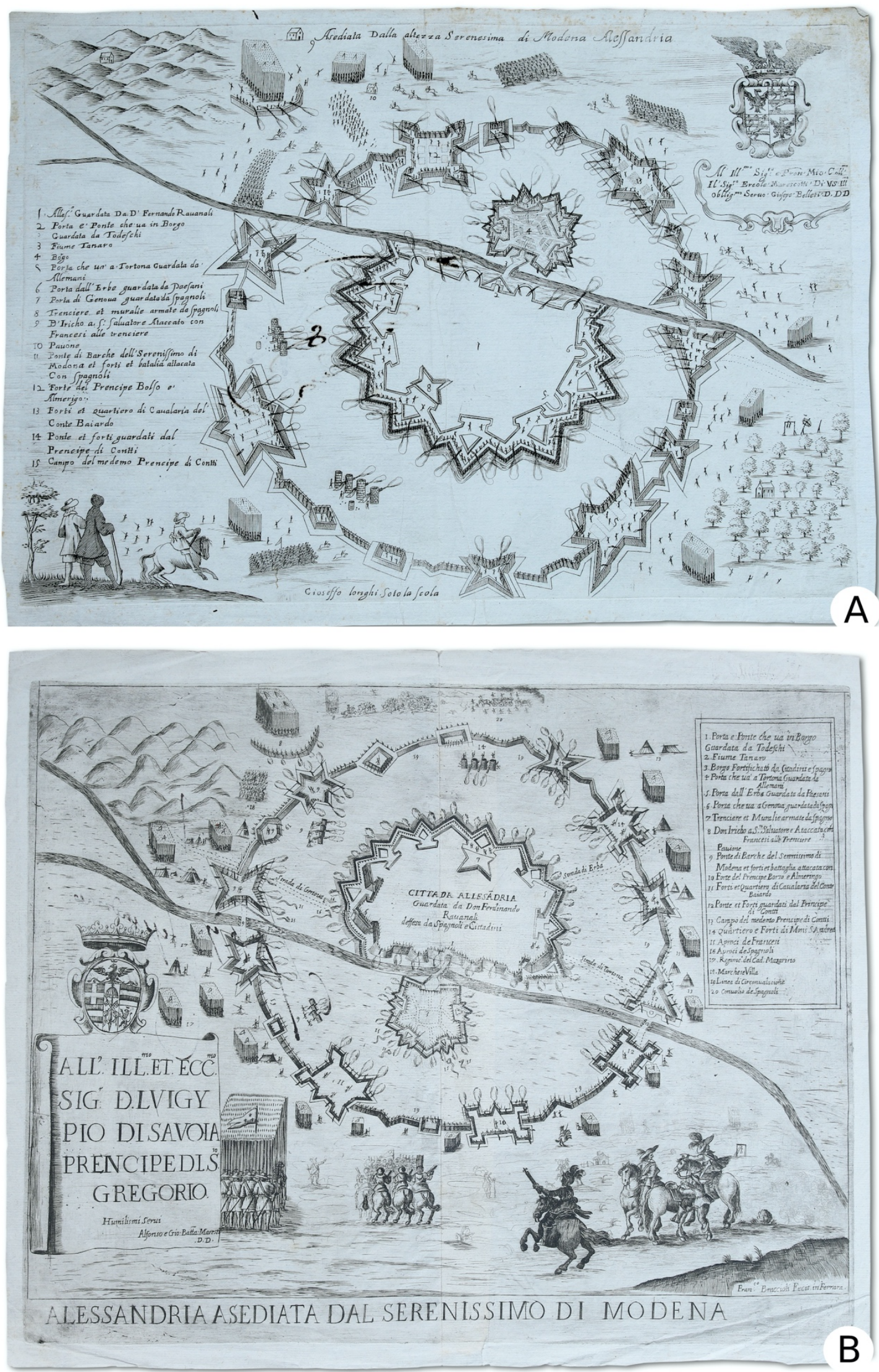

Figure 2. Two Plans of the siege of Alessandria: A. map number 50, B. map number 51 (etching and engraving, printed on paper, ASMO Mappario Estense, Serie Generale). 


\begin{tabular}{|c|c|}
\hline People involved & Gioseppe Belleti (mapmaker), Gioseffo Longhi soto la scola (etcher) \\
\hline Physical properties & Watermark: Indistinct. Condition: no fold lines. Verso: none \\
\hline Measurements & $\begin{array}{l}40.0 \times 28.5 \mathrm{~cm} \text { (image and sheet) } \\
\text { The scale of the town is greatly enlarged compared with the scale of the details } \\
\text { of the surrounding country }\end{array}$ \\
\hline \multirow[t]{4}{*}{ Transcriptions } & $\begin{array}{l}\text { Printed title: Asediata dalla altezza Serenissima di Modena Alessandria [top left, } \\
\text { in rectangular space] }\end{array}$ \\
\hline & $\begin{array}{l}\text { Dedication: Al Ill.mo Sig.ro e Pron. Mio. Coll.mo Il Sig.ro Ercole Marescotti Di } \\
\text { VS Ill.mo Obllig.mo Servo Giosepe Belleti D.DD [upper right, in decorative } \\
\text { semi-circular cartouche under the crest] } \\
\text { Marescotti crest [upper right, over the dedication] }\end{array}$ \\
\hline & Additional text: a key, 1-15 [left, in rectangular space] \\
\hline & Annotations: (Recto) none (Verso) none \\
\hline Places & Alessandria, Piedmont, Italy $\left(44^{\circ} 54^{\prime} 33^{\prime \prime} \mathrm{N} 08^{\circ} 36^{\prime} 36^{\prime \prime} \mathrm{E}\right)$ \\
\hline Date & n.d. (not before 1657) \\
\hline
\end{tabular}

Table 2. The main cartographic features of the Map n. 50 of the siege of Alessandria (fig. 2A).

\begin{tabular}{|c|c|}
\hline People involved & $\begin{array}{l}\text { Alfonso e Giovan Battista Maresti (mapmakers), Francesco Braccioli Fecit in } \\
\text { Ferrara (etcher) }\end{array}$ \\
\hline Physical properties & Watermark: Indistinct. Condition: no fold lines. Verso: none \\
\hline Measurements & 28.7 x $38.6 \mathrm{~cm}$ (image and sheet) \\
\hline \multirow[t]{4}{*}{ Transcriptions } & $\begin{array}{l}\text { Printed title: Dichiaratione del Armata Imperiale contra l'Armata del Re di } \\
\text { Svezia disposti alla Battaglia fra la Villa di Lutzen, et il Bosco il dì } 15 \text { novb. } 1632 \\
\text { [top left, in rectangular panel] }\end{array}$ \\
\hline & $\begin{array}{l}\text { Dedication: All' Ill. }{ }^{\text {mo }} \text { Sig. }{ }^{\mathrm{r}} \text { ASTOR ORSI Cavalliere di S. Giacomo E Dign. }{ }^{\mathrm{mo}} \\
\text { Capitano di Cavalli in Bologna. Pietro Batalia D.D.D. [bottom, in rectangular } \\
\text { panel across top of map] }\end{array}$ \\
\hline & Additional text: a key, A-O, P-\& [top right, in rectangular panel, below title] \\
\hline & Annotations: (Recto) Lutzen 149, black pencil (Verso) none \\
\hline Places & $\begin{array}{l}\text { Lützen, Saxony-Anhalt, Germany }\left(51^{\circ} 15^{\prime} 24^{\prime \prime} \mathrm{N} 12^{\circ} 08^{\prime} 29^{\prime \prime} \mathrm{E}\right) \\
\text { Ripach (Rippach), Saxony-Anhalt, Germany }\left(51^{\circ} 13^{\prime} 59^{\prime \prime} \mathrm{N} 12^{\circ} 04^{\prime} 00^{\prime \prime} \mathrm{E}\right) \\
\text { Waisenfelz (Weißenfels), Saxony-Anhalt, Germany }\left(51^{\circ} 12^{\prime} \mathrm{N} 11^{\circ} 58^{\prime} \mathrm{E}\right)\end{array}$ \\
\hline Date & $15^{\text {th }}$ November 1632 \\
\hline
\end{tabular}

Table 3. The main cartographic features of the Map n. 51 of the siege of Alessandria (fig. 2B).

\section{Observations on map}

The map of the battle of Lützen (fig. 1, tab. 1) is very effective in communicating the power of the two sides neatly arranged in a large number of infantry, cavalry and artillery troop formations. The observer of the map is placed on the side of the imperial array facing the army of the King of Sweden.

A dry ditch (F: fosso sutto) separates the two camps and on the right side of the imperial camp is the village of Lützen, which almost disappears in the face of the massive armed deployment (about twenty thousand units per deployment).

The focus is on the depiction of the two vignettes of the clash of cavalry skirmish armed with swords and troops firing arms, in which the Count of Pappenheim (key O) and King Gustav of Sweden (key T) lost their lives. The violence of both clashes is effectively rendered by a tight interweaving of swords, horses and armed soldiers.

\subsection{Two Maps of the siege of Alessandria}

\subsubsection{Historical context}

In 1647, for political expediency, Francesco I moved closer to France, establishing relations with Mazarin, the powerful advisor to the King of France and uncle of Laura Martinozzi, who was to become the wife of his son Alfonso IV d'Este in 1654. Francesco thus became commander of the French troops in Italy and led several campaigns against Spanish strongholds, including the city of Alessandria.

The siege of the city of Alessandria (17 July - 19 August 1657) was an event of the Franco-Spanish war (16351659) which also involved states in northern Italy, notably the State of Milan (allied to the Spanish) and the Duchy of Savoy (allied to the French). The siege in the summer of 1657 saw the Spanish-Lombard army coming to the aid of the besieged Alexandrians, in agreement with the Swiss, the Austrians and Charles II Duke of Mantua. The other 
side was opposed by the Franco-Sabaudian army, commanded by Armando di Borbone Prince of Conti and Marquis Gianfranco Villa, who made use of the alliance with Duke Francesco I.

The Este family was historically linked to the Empire and therefore theoretically an ally of the Spanish, but during the years of his duchy, Francesco I changed sides and alliances more than once, in a continuous succession of negotiations and peace treaties that were always aimed at increasing the power and rank of his Family. The city of Alessandria was recaptured on $19^{\text {th }}$ August by Spanish forces.

\subsubsection{Observations on maps}

The two maps (fig. 2A, B; tab. 2,3) show the town of Alessandria placed on the right bank of the Tanaro River, with its settlement (Borgo) on the opposite river bank. Both maps provide an accurate reconstruction of the military forces on the field where the siege took place.

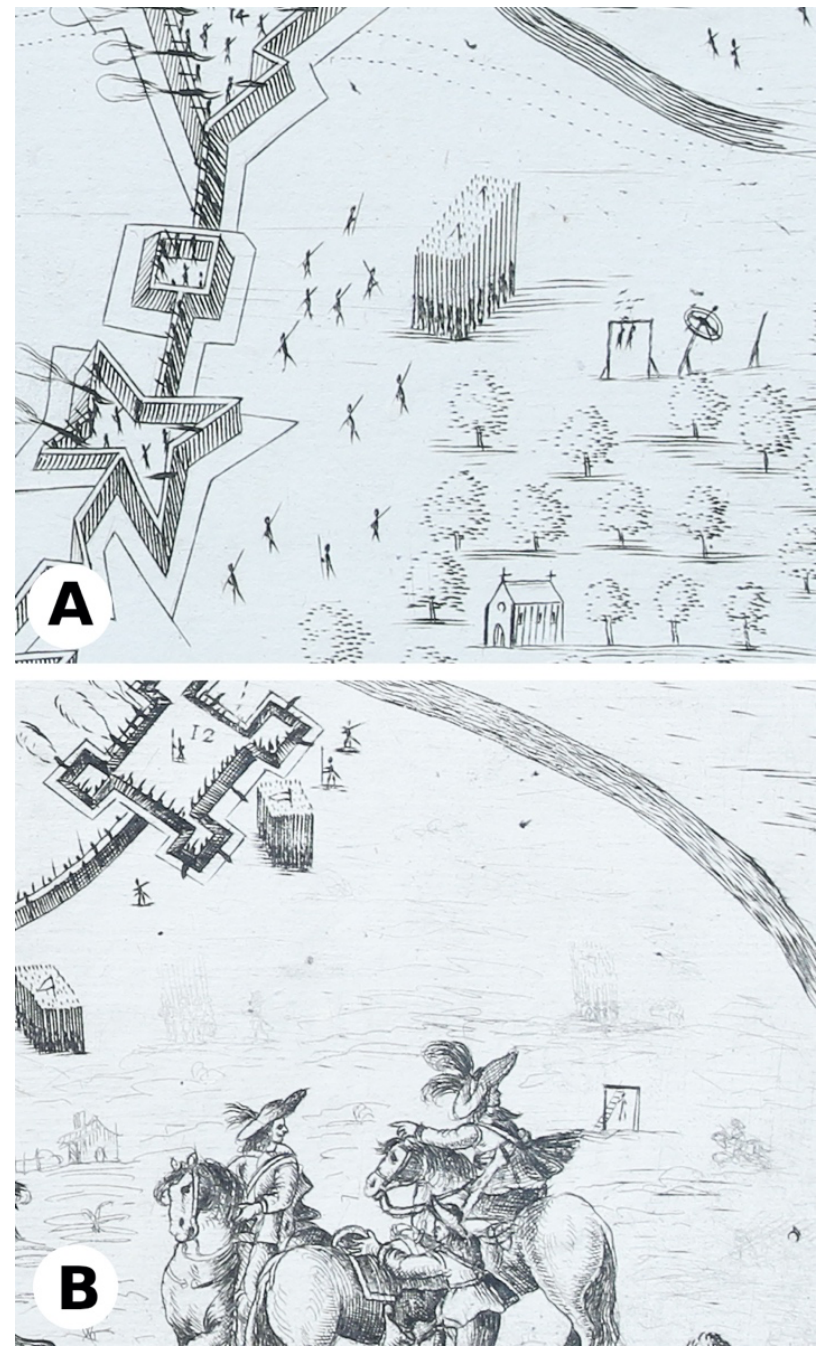

Figure 3. Similar cartographic details of the area of capital punishment (such as hanging) in a wooded area in the lower right-hand corner of the sheets in Alessandria maps, number 50 (A) and number 51 (B).
A detailed key explains the location of the forts and districts of the main protagonists: the defensive troops led by the Spanish governor Fernando Garcia Ravanal, and the besiegers' camps of Francesco I and the Princes Borso (the Duke's uncle), and Almerigo (the Duke's younger son who followed his father in military exploits).

The maps show similar cartographic details of the morphological features of the land (the hills on the upper left corner and a wooded area in the opposite right side, fig. 2) and some elements related to the siege surrounding the town, as the clash with Spanish forces on the upper lefthand side and the area of capital punishment on the lower right-hand side (fig. 3), such as hanging, Catherine wheel etc.

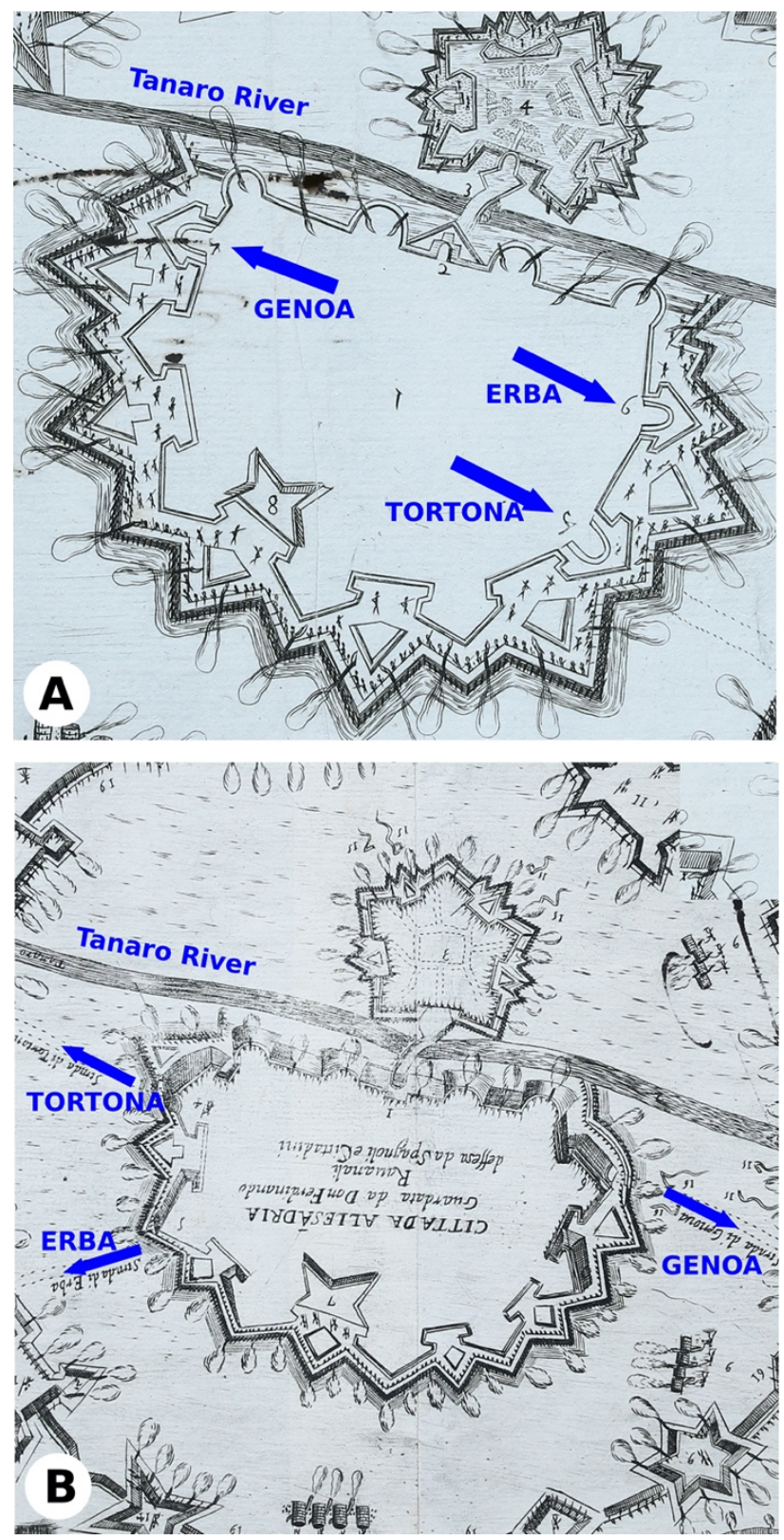

Figure 4. Some topographical inconsistencies between the Alessandria maps, number 50 (A) and number 51 after $180^{\circ}$ rotation (B): the main road directions are mirrored to each other. 
The study of the two Alessandria maps has highlighted some topographical inconsistencies (fig. 2). If we make the maps coincide with the Tanaro river (by rotating map 51 by $180^{\circ}$ ), the inconsistencies linked to the topography of the town of Alessandria are evident (fig. 4). The position of the city gates towards Genoa, Tortona and Erba, and their respective road directions appear to be mirrored in map 51 (fig. 4B). This curious cartographic incongruity leads to the hypothesis of a mistake during the mapmaking of Alessandria siege number 51, which may have been carried out at different times by an engraver who was not an expert in the Alessandria area, perhaps even reusing or updating a previous map.

Both maps presumably played both an informative role at the time regarding the events of the siege and a celebratory role towards the Este family.But nowadays they are still worthy of interest with respect to: historical, geographic and educational points of view.

\section{Conclusion}

The digitalisation of historical maps has opened up new perspectives for communication with the general public by encouraging the construction of a kind of personal digital library. Digital systems for the reproduction and processing of any type of image today allow a range of interventions, interactions and manipulations that multiply the possibilities for study and research, and at the same time represent useful tools for educational and dissemination activities.

Maps as a means of communicating the past are flanked by what they can communicate today, not only about the political and cultural history of duchies, governments and states, but also and especially about the physicalgeographical history of territories, their evolution and anthropic impact over the centuries.

The structure of the project "Experiences of promotion and fruition using historical maps" foresees the launch of activities with high schools related to themed studies or work experience (PCTO in Italy), aimed at providing scientific knowledge of the value of cartographic heritage and the reading of historical maps from different points of view.

One of the main purposes of the project is to create a virtual exhibition, in order to enhance the digitized maps and their digital contents related to the "AI for Digital Humanities" project of Modena and Reggio Emilia University. The virtual exhibition will be able to overcome any structural, cultural and health barriers, and involve users in an experience of discovery, knowledge and individual learning.

\section{Acknowledgements}

The authors sincerely acknowledge Patrizia Cremonini (director), Lorenza Iannacci and Annalisa Sabatini of the State Archive of Modena for their precious support for the project.

\section{Attributions}

The setting and bibliographic research are common; L.M. Turchi edited the paragraphs on 'historical context' $n$. 3.1.1 and 3.2.1., M. Bertacchini edited the other paragraphs.

\section{References}

Baker, A.R.H. (2005). Réflexions sur les relations entre l'histoire et la géographie, in P. Boulanger P. and J.R. Trochet (eds.), Où en est la géographie historique? Entre économie et culture, Paris, L'Harmattan, 19-31.

Cremonini, P. (2017). Note sulle testimonianze dell'Archivio di Stato di Modena. Con riferimento alle relazioni Stato estense - Regno d'Ungheria. Rivista di Studi Ungheresi, RSU, 16, 105-154.

Dai Prà, E. (ed.) (2010). La cartografia storica da bene patrimoniale a strumento progettuale, Semestrale di Studi e Ricerche di Geografia, La Sapienza, Roma, Nuova Cultura.

Farinelli, F. (1992). I segni del mondo. Immagine cartografica e discorso geografico in età modernaLa Nuova Italia, $226 \mathrm{pp}$.

Federzoni, L. (2001). Gli Stati di Casa d'Este nella cartografia, in A. Spaggiari and G. Trenti (eds.), Lo Stato di Modena. Una capitale una dinastia, Ministero per i Beni e le Attività Culturali, Roma, 451-480.

De Ponzio, L. (2021). Esperienze di promozione e fruizione attraverso la digitalizzazione di mappe storiche. Tesi di laurea magistrale, Didattica e Comunicazione delle Scienze, Dipartimento di Scienze Chimiche e Geologiche, Università di Modena e Reggio Emilia.

Rombai, L. (2010). Le problematiche relative all'uso della cartografia storica, Bollettino dell'Associazione Italiana di Cartografia, 138, 69-89.

Rossi M., 2006. La geografia del Furioso. Sul sapere geocartografico alla corte estense, in $\mathrm{P}$. Trovato and $\mathrm{M}$. Bordin (eds.), Lucrezia Borgia storia e mito, Leo S. Olschki, Firenze, 97-138. 